конференции «Современные методы диагностики и лечения заболеваний слезных органов». - М., 2005. C.103-106.

16. Малиновский Г. Ф. Современные методы обследования и лечения больных с дакриоциститами новорожденных: Учеб. - метод пособие / Г.Ф, Малиновский - Мн., 2005 - С.15

17. Риков С. О., Еміліт В. А., Барінов Ю. В. Порушення сльозовідведення у дітей, причини, діагностика та способи усунення // Актуальні проблеми медикосоціальної реабілітації дітей з інвалідизуючою очною патологією: III наукова-практична конференція (4-6 жовтня 2006 р.). - Євпаторія, 2006. - С. 275-291.

18. Тахчиди Х. П., Малюгин Б. Э., Аскерова С. М. Анализ причин и меры предупреждения рецидивов после операций на слезных канальцах // Вестн. Офтальмол. - 2005. - № 3. - С. 20-22.

19. Ушакова Н. А., Порицкий Т. А., Лушникова Т. А., Лисовская Т. А. // Сборник трудов научно - практиче- ской конференции «Современные методы диагностики и лечения заболеваний слезных органов». - М., 2005. - С.277-278.

20. Эмилит В. А., Рыков С. А., Баринов Ю. В. Методика восстановления проходимости слезопроводящих путей // Хірургічне лікування та реабілітація хворих з офтальмологічною патологією: матеріали науковопрактичної конференції (7-8 жовтня 2004 р.). - Київ, 2004. - C. - 258-259.

21. Adam J. Cohen, Michael Mercandetti, Brian G. Brazzo. The Lacrimal System: Diagnosis, Management and Surgery / New York: Springer, 2006. - 99-273 p.

22. Thomas J. Liesegang, Thomas A. Deutsch, M. Gilbert Grand. The Basic and Clinical Science Course. Section 7: Orbit, Eyelids, and Lacrimal System / San Francisco: Copyright, 2002. - 2003. - 221-256 p.

Поступила 30.03.2011. Рецензент д-р мед. наук, проф. Н. Ф. Боброва

\title{
RECURRENT DACRYOCYSTITIS TREATMENT IN CHILDREN OF YOUNGER AGE
}

\section{S. A. Rykov, Yu. V. Barinov, A. A. Barinova}

\section{Kiev, Ukraine}

The aim of our work was to study the effectiveness of the proposed method of renewal of the lachrymal duct flow using a mixture of viscoelastic and antibiotic in case of recurrent dacryocystitis in younger age children. According to the technique we have proposed probing and bougienage of the lachrymal duct with the following retrograde filling of the new formed canal with viscoelastic. We have treated 54 children with recurrent dacryocystitis at the age from 3 months to 5 years old. Lacrymation was totally reconstructed in $89 \%$ of patients younger than 3 years old. This method of treatment is easy, effective, low traumatic and does not need involvement of special surgical instruments.

Удк: $617.7 /(477): 001.5+614.2 / 615.851 .859$

\section{ОЦІНКА ДОСТУПНОСТІ СІЛЬСЬКОГО НАСЕЛЕННЯ ДО ЯКІСНОЇ ОФТАЛЬМОХІРУРГІЧНОЇ ДОПОМОГИ В СТАЦІОНАРНИХ УМОВАХ}

\author{
О. М. Черемухіна, канд. мед. наук.
}

Київська міська клінічна офтальмологічна лікарня «Центр мікрохірургії ока»

\begin{abstract}
Установлено, что использование сети и коечного фонда стационарных глазных отделений в центральных районных больницах является малоэффективным и не обеспечивает высокой доступности сельского взрослого населения к качественной офтальмохирургической помощи, а также не способствует снижению ее себестоимости на государственном уровне. Предложены пути решения существующей проблемы.
\end{abstract}

Ключевые слова: болезни глаза и его придатков, медицинская помощь, стационар, доступность, эффективность, сельское население.

Ключові слова: хвороби ока та його придатків, медична допомога, стаціонар, доступність, ефективність, сільське населення.

Вступ. Скрутна економічна ситуація в країні, яка визначається значним обмеженням державного фінансування галузі охорони здоров'я України, а також наявні проблеми управлінням нею: дублювання медичних послуг на різних рівнях надання медичної допомоги, відсутність механізму управління потоками пацієнтів на різних рівнях надання медичних послуг; низька самостійність медичних закладів при використанні фінансових ресурсів - все це визначає нагальну необхідність до реформування галузі, шляхом

(C) О. М. Черемухіна, 2011 
підвищення ефективності використання наявних ресурсів та оптимізації системи управління [1-3].

Офтальмологічна патологія є однією із поширеніших серед населення України і також є провідною причиною обмеження життєдіяльності та працездатності населення країни [4, 5]. Відсутність адекватних заходів, щодо надання допомоги хворим із цією патологією призведе до незворотніх негативних соціально-економічних наслідків [4].

До теперішнього часу не проводились дослідження щодо оцінки доступності сільського населення до якісної офтальмохірургічної допомоги в умовах стаціонару, що і визначило актуальність даного дослідження.

Метою дослідження визначено: оцінити доступність сільського населення до офтальмохірургічної допомоги в стаціонарних умовах.

МАТЕРІАЛ ТА МЕТОДИ. Проведено аналіз первинних даних, отриманих від Центру медичної статистики МОЗ України, щодо стану мережі, ліжкового фонду та показників ефективності діяльності стаціонарних офтальмологічних відділень, які надають допомогу дорослому населенню сільській місцевості України (за період 2002-2008 р.р.).

Дані оброблялись методами варіаційної статистики. Визначення динаміки показників (ДП) проводилось відповідно до формули 1, де: П - показник на обраний час дослідження; $\Pi_{0}-$ попередній показник (на початок дослідження).

$$
\text { ДП }=\frac{\Pi_{\mathrm{t}}-\Pi_{0}}{\Pi_{0}} \times 100 \%,
$$

Для встановлення статистичного зв'язку між показниками використано непараметричний кореляційний аналіз Спірмена $\left(\mathrm{r}_{\mathrm{sp}}\right)$.

Під час проведення дослідження не було потреби в отриманні інформованої згоди внаслідок використання неперсоналізованої первинної інформації.

РЕЗУЛЬТАТИ ДОСЛІДЖЕННЯ ТА ЇХ ОБГОВОРЕННЯ. Надання спеціалізованої (II рівень) та висококваліфікованої (III рівень) офтальмологічної допомоги в Україні відбувається в стаціонарних очних відділеннях (потужністю від 20 до 200 ліжок), розташованих у центральних районних (ЦРЛ) та в обласних (ОЛ) лікарнях та обласних офтальмологічних лікарнях (ОфЛ) (в Дніпропетровській та Миколаївській областях).

Стаціонарна допомога дорослим офтальмологічним хворим, що мешкають у сільській місцевості, на вторинному та третинному рівнях у 2002 році надавалась у 145 відділеннях (в ЦРЛ - 121; в ОЛ 24; ОфЛ - 2), на 3357 спеціалізованих ліжках.

До 2008 року мережа очних відділень скоротилась на 4,1 \% (в ЦРЛ - на 4,9\%), а ліжковий фонд - на 10,3 \% (ЦРЛ - на 16,6\%; ОЛ - на 3,1\%). В цілому за період 2002-2008 р.р. по Україні спостерігається скорочення шести очних відділень та 297 ліжок в ЦРЛ та на 48 ліжок в ОЛ. Мережа та ліжковий фонд обласних офтальмологічних лікарень залишались стабільними (рис. 1).

Дослідженням визначено, що на рівні ЦРБ відбувались наступні зміни:

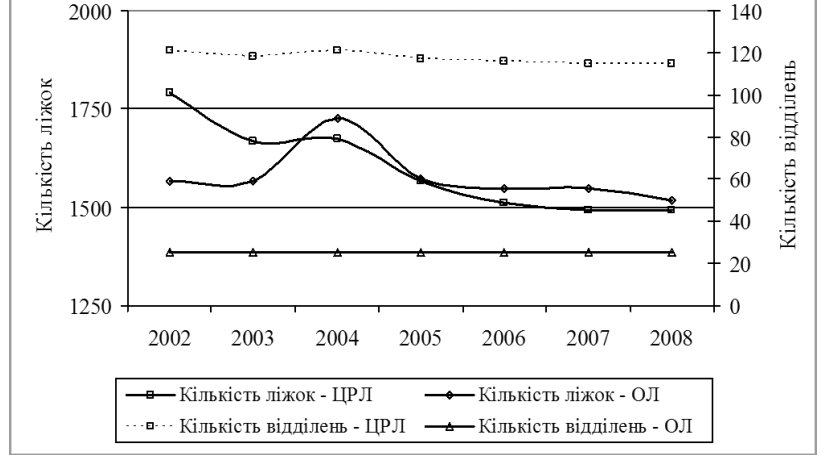

Рис. 1. Динаміка мережі очних відділень та ліжковий фон в центральних районних лікарнях (ЦРЛ) та обласних лікарнях (ОЛ) в Україні

- розширення мережі відділень із скороченням ліжкового фонду у Запорізькій, Київській та Вінницькій областях (12,0\% областей);

- стабільність мережі із збільшенням ліжкового фону - АР Крим (4,0 \%);

- стабільність мережі та ліжкового фонду - у Миколаївській, Чернівецькій, Волинській, Кіровоградській, Луганській, Херсонській, Донецькій областях (28,0\%);

- стабільність мережі із скороченням ліжкового фонду - у Полтавській, Черкаській, ІваноФранківській, Львівській, Чернігівській, Закарпатській, Одеській, Дніпропетровській областях $(32,0 \%)$;

- скорочення мережі та ліжкового фонду - в Сумській, Рівненській, Житомирській, Хмельницькій, Тернопільській, Харківській областях (24,0\%).

На рівні обласних лікарень спостерігалось:

- розширення мережі із стабільністю ліжкового фонду - в Запорізькій області та АР Крим (8,0 \%);

- скорочення мережі із стабільністю ліжкового фонду - в Тернопільській, Донецькій, Черкаській, Івано-Франківській, Полтавській областях (20,0\%);

- стабільність мережі та ліжкового фонду - в інших 18 областях (72,0\%).

Також спостерігалось і суттєве скорочення терміну перебування хворих на офтальмологічному ліжку, що є свідченням впровадження нових технологій та покращення організації лікувальнодіагностичного процесу в областях із низьким показником тривалості знаходження хворих у стаціонарі. Аналіз динаміки середнього ліжко-дня перебування у офтальмологічному відділенні вказує на його скорочення впродовж 2002-2008 р.p. на 15,5 \% (з 10,3 до 8,7 днів) і в середньому за цей період він становив - 9,5 днів. Найбільше за середній показник (>10,0 днів) перебування хворих спостерігалось в: Івано-Франківській, Одеській, Запорізькій, Чернігівській, Донецькій, Львівській, Рівненській областях. А найменші (<9,0 днів) - у Сумській, Вiнницькій, Житомирській, Харківській, Черкаській, Київській областях (табл. 1). 
Динаміка середнього ліжка-дня очних відділень (ліжко-день)

\begin{tabular}{|l|c|c|c|c|c|c|c|c|}
\hline \multirow{2}{*}{\multicolumn{1}{|c|}{ Області }} & \multicolumn{7}{c}{ Показик ліжко-день } & Середнє \\
\cline { 2 - 8 } & $\mathbf{2 0 0 2}$ & $\mathbf{2 0 0 3}$ & $\mathbf{2 0 0 4}$ & $\mathbf{2 0 0 5}$ & $\mathbf{2 0 0 6}$ & $\mathbf{2 0 0 7}$ & $\mathbf{2 0 0 8}$ & значення \\
\hline Івано-Франківська & 11,2 & 11,1 & 10,7 & 10,3 & 18 & 9,7 & 9,4 & 11,5 \\
\hline Одеська & 12,4 & 12,3 & 11,2 & 10,5 & 10,2 & 12 & 9,9 & 11,2 \\
\hline Запорізька & 12,0 & 11,2 & 10,9 & 10,6 & 10,4 & 10,4 & 10,2 & 10,8 \\
\hline Чернігівська & 12,5 & 11,9 & 11,3 & 10,4 & 10,4 & 9,6 & 9,1 & 10,7 \\
\hline Донецька & 13,0 & 10,2 & 10,0 & 9,8 & 9,7 & 9,5 & 9,5 & 10,2 \\
\hline Львівська & 11,4 & 10,8 & 10,5 & 9,9 & 9,8 & 9,6 & 9,1 & 10,2 \\
\hline Рівненська & 10,8 & 10,6 & 10,6 & 10,3 & 10,2 & 9,8 & 9,4 & 10,2 \\
\hline Дніпропетровська & 10,6 & 10,5 & 10,2 & 9,7 & 9,4 & 8,9 & 9,1 & 9,8 \\
\hline Херсонська & 9,9 & 14,0 & 9,8 & 9,3 & 9,0 & 8,5 & 8,0 & 9,8 \\
\hline Луганська & 11,0 & 10,5 & 9,8 & 9,6 & 9,3 & 8,7 & 8,6 & 9,6 \\
\hline Чернівецька & 9,9 & 9,8 & 9,6 & 9,6 & 9,5 & 9,5 & 9,3 & 9,6 \\
\hline АР Крим & 9,3 & 9,3 & 9,3 & 9,4 & 9,4 & 9,6 & 9,9 & 9,5 \\
\hline Миколаївська & 10,4 & 10,1 & 9,6 & 9,4 & 9,3 & 9,1 & 8,8 & 9,5 \\
\hline Середнє значення & 10,3 & 10,1 & 9,6 & 9,3 & 9,5 & 8,9 & 8,7 & 9,5 \\
\hline Кіровоградська & 10,7 & 10,3 & 9,6 & 9,5 & 8,9 & 8,2 & 7,8 & 9,3 \\
\hline Полтавська & 9,8 & 9,5 & 9,4 & 9,2 & 9,0 & 8,8 & 8,5 & 9,2 \\
\hline Хмельницька & 10,5 & 9,4 & 9,0 & 9,0 & 9,3 & 8,8 & 8,7 & 9,2 \\
\hline Волинська & 9,7 & 10,2 & 9,8 & 9,4 & 8,6 & 8,3 & 7,7 & 9,1 \\
\hline Закарпатська & 10,2 & 9,6 & 9,2 & 8,8 & 8,7 & 8,4 & 8,8 & 9,1 \\
\hline Тернопільська & 9,7 & 9,3 & 9,1 & 8,9 & 9,0 & 8,5 & 8,7 & 9,0 \\
\hline Сумська & 8,9 & 8,9 & 8,6 & 8,8 & 8,8 & 8,6 & 8,5 & 8,7 \\
\hline Вінницька & 9,0 & 8,7 & 8,8 & 8,5 & 8,4 & 7,9 & 8,1 & 8,5 \\
\hline Житомирська & 9,0 & 8,6 & 8,3 & 8,4 & 8,4 & 8,3 & 7,9 & 8,4 \\
\hline Харківська & 9,6 & 8,8 & 8,4 & 8,2 & 8,1 & 7,5 & 7,2 & 8,3 \\
\hline Черкаська & 8,7 & 8,5 & 8,5 & 8,3 & 8,0 & 7,9 & 7,9 & 8,3 \\
\hline Київська & 8,4 & 8,4 & 8,4 & 7,9 & 7,8 & 7,6 & 7,6 & 8,0 \\
\hline
\end{tabular}

Аналіз динаміки хірургічної активності очних стаціонарів, які обслуговують дорослих сільських мешканців, свідчить, що даний показник впродовж 2002-2008 p.p. є невисоким і становить $-57,9 \%$, що вказує на неефективне використання високовартісних ресурсів для реалізації хірургічного лікування хворих в стаціонарних умовах та зайняття стаціонарних ліжок для офтальмотерапевтичного лікування. Лише в чотирьох областях України цей показник є більшим за 70,0 \% - у Вінницькій, Миколаївській, Херсонській та Волинській, що свідчить про ефективне управління наявними обмеженими ресурсами стаціонарної офтальмологічної допомоги населенню. Найгірша ситуація спостерігається в шести областях, де хірургічна активність в стаціонарах становить менше 50,0 \% - в Київській, Сумській, Одеській, Закарпатській, Чернігівській та Івано-Франківській (табл. 2).

Середнє забезпечення мешканців сільської місцевості хірургічними втручаннями на оці у стаціонарних умовах впродовж 2002-2008 p.p. становило $-27,9$ на 10 тис. сільського населення. Найвищі рівні цього показника (> 35,0 на 10 тис. відповідного населення) спостерігаються у Вінницькій, Сумській, Донецькій областях, а найнижчі $(<20,0$ на 10 тис.) - у Київській, Тернопільській, Одеській та Івано-Франківській областях (табл. 3).
На нашу думку, досить низькі показники оперативних втручань в Київський та Одеській областях пояснюються тим, що у переважній більшості надання офтальмохірургічної допомоги у них відбувається на базі Київської міської клінічної офтальмологічної лікарні «Центр мікрохірургії ока» (і дані входять до статистики по м. Києву) та в ДУ «Інститут очних хвороб та тканинної терапії ім. В. П. Філатова АМН України» (дані входять до статистики по АМН України і не включаються до даних МО3).

Одним із напрямків зниження собівартості лікування офтальмологічних хворих є впровадження системи надання медичної допомоги в амбулаторних закладах. Це також є актуальним і для офтальмологічної служби, коли в амбулаторних умовах можуть виконуватись малоінвазивні хірургічні втручання. Аналіз даних показав, що забезпеченість сільського населення такими втручаннями впродовж 2002-2008 p.p. була вкрай низькою і в середньому становила $-26,2$ операцій на 10 тис. сільського дорослого населення. Краща ситуація спостерігалась лише в чотирьох областях, де цей показник був більше за 40,0 на 10 тис. відповідного населення: у Вінницькій, Волинській, Рівненській, Сумській. А найгіршій $(<15,0$ на 10 тис. відповідного населення) в: Одеській, Миколаївській, Львівській, Київській областях (табл. 4). 
Таблиця 2

Динаміка хірургічної активності очних стаціонарів ( \%)

\begin{tabular}{|l|c|c|c|c|c|c|c|c|}
\hline \multirow{2}{*}{\multicolumn{1}{|c|}{ області }} & \multicolumn{7}{|c|}{ Показник хірургічної активності очних стаціонарів (\%) } & \multicolumn{2}{c|}{ Середнє } \\
\cline { 2 - 8 } & $\mathbf{2 0 0 2}$ & $\mathbf{2 0 0 3}$ & $\mathbf{2 0 0 4}$ & $\mathbf{2 0 0 5}$ & $\mathbf{2 0 0 6}$ & $\mathbf{2 0 0 7}$ & $\mathbf{2 0 0 8}$ & значення \\
\hline Вінницька & 80,1 & 75,5 & 77,6 & 80,8 & 81 & 84,2 & 82,4 & 80,2 \\
\hline Миколаївська & 70,3 & 67,5 & 83,7 & 79,5 & 80,8 & 79,1 & 77,3 & 76,9 \\
\hline Херсонська & 76,8 & 71,9 & 69,7 & 71,5 & 73 & 77,5 & 74,8 & 73,6 \\
\hline Волинська & 69 & 67,2 & 72,6 & 78,8 & 77,9 & 74,9 & 72,3 & 73,2 \\
\hline Донецька & 75,4 & 64,4 & 64,3 & 65,5 & 64 & 64,5 & 65,1 & 66,2 \\
\hline Житомирська & 69,4 & 64,7 & 62,3 & 64,7 & 64,5 & 66,2 & 66,1 & 65,4 \\
\hline АР Крим & 71,9 & 64,1 & 59,6 & 59,8 & 57,5 & 60,8 & 61,2 & 62,1 \\
\hline Черкаська & 62,8 & 53,6 & 57,4 & 59,6 & 61 & 65,6 & 68,1 & 61,2 \\
\hline Рівненська & 67,8 & 56,1 & 62,9 & 59,4 & 59,5 & 60 & 60,9 & 60,9 \\
\hline Харківська & 66,3 & 62,9 & 59,1 & 59,1 & 57,7 & 57,2 & 62,3 & 60,7 \\
\hline Запорізька & 58,1 & 60,5 & 64,2 & 62,3 & 58,9 & 60,5 & 59,5 & 60,6 \\
\hline Дніпропетровська & 59 & 57,5 & 61,2 & 64,3 & 65,1 & 58,7 & 54,7 & 60,1 \\
\hline Полтавська & 58,4 & 58,4 & 59,6 & 58,3 & 58,2 & 59,7 & 62,1 & 59,2 \\
\hline Середнє значення & 60,9 & 54,3 & 58,3 & 58,3 & 57,8 & 58,3 & 57,5 & 57,9 \\
\hline Тернопільська & 54,9 & 48,1 & 51,2 & 55,4 & 60,8 & 59,9 & 59,6 & 55,7 \\
\hline Кіровоградська & 53,1 & 52,7 & 55,2 & 58,8 & 54,2 & 54,7 & 56,5 & 55,0 \\
\hline Хмельницька & 50,6 & 51,2 & 56,6 & 59 & 57,8 & 56,3 & 53,3 & 55,0 \\
\hline Чернівецька & 57,4 & 54,9 & 57,4 & 57,8 & 54,3 & 52,4 & 48,8 & 54,7 \\
\hline Луганська & 60,6 & 55,2 & 54,7 & 54,1 & 51,2 & 51,5 & 52 & 54,2 \\
\hline Львівська & 52,2 & 45,5 & 50,2 & 48,9 & 50,8 & 56,7 & 59,2 & 51,9 \\
\hline Київська & 77,6 & 19,4 & 69,2 & 44 & 42,9 & 44 & 45,5 & 48,9 \\
\hline Сумська & 53,4 & 47,6 & 48 & 48,3 & 48 & 48,1 & 45,4 & 48,4 \\
\hline Одеська & 52,1 & 47,2 & 46,6 & 47 & 46,7 & 44,4 & 42,9 & 46,7 \\
\hline Закарпатська & 48,5 & 43,2 & 47,9 & 48,1 & 46,6 & 51,4 & 38,7 & 46,3 \\
\hline Чернігівська & 41,8 & 36,8 & 35,6 & 40,8 & 40,8 & 38,1 & 38,3 & 38,9 \\
\hline Івано-Франківська & 35,7 & 31,6 & 31,5 & 32,7 & 32,8 & 30,7 & 30,8 & 32,3 \\
\hline
\end{tabular}

Амбулаторні операції в середньому становлять 48,4 \% від усіх проведених оперативних втручань на оці. Переважають амбулаторні втручання у: Волинській, Рівненській, Вінницькій, Івано-Франківській, Житомирській, Тернопільській, Хмельницькій, Чернівецькій, Полтавській, Сумській областях (табл. 4).

Якщо порівняти області із низьким рівнем забезпечення населення оперативними втручаннями у стаціонарних умовах та значну частку операцій в амбулаторних умовах, від загальної кількості офтальмохірургічних втручань, то можна говорити, що у Волинській, Рівненській, Тернопільській, Хмельницькій, Чернівецькій та Полтавській областях відбуваються позитивні зміни, внаслідок проведення частки хірургічних втручань в амбулаторних умовах, що сприяє зниженню собівартості цієї допомоги в цілому.

Однак негативні тенденції, які пов'язані із низькою доступністю населення до офтальмохірургічних методів лікування, спостерігаються в: Херсонській, Львівській, Кіровоградській, Закарпатській, Черкаській та Івано-Франківській областях, де доступність населення до такої допомоги як в умовах стаціонару, так і в амбулаторних умовах - $є$ наднизькою, що потребує прийняття відповідних організаційних та кадрових рішень, спрямованих на виправлення існуючої ситуації.

Проведеним непараметричним кореляційним аналізом Спірмена встановлено, що існує негативна вірогідна статистична залежність між кількістю очних відділень $\left(\mathrm{r}_{\mathrm{sp}}=-0,41, \mathrm{p}<0,05\right)$, ліжковим фондом в ЦРЛ $\left(\mathrm{r}_{\mathrm{sp}}=-0,53, \mathrm{p}<0,05\right)$ та хірургічною активністю у них. В свою чергу, між хірургічною активністю відділень та забезпеченням населення офтальмохірургічними втручаннями існує пряма й вірогідна статистична залежність ( $\left.\mathrm{r}_{\mathrm{sp}}=0,46, \mathrm{p}<0,05\right)$. Тобто, чим більше відділень та ліжок в ЦРЛ - тим менше хірургічна активність у них, і відповідно - менше забезпечення населення офтальмохірургічними втручаннями у стаціонарних умовах. Це вказує на те, що і до теперішнього часу існує нераціональне використання ліжкового фонду в очних відділеннях ЦРЛ, а мережа таких відділень $є$ необгрунтовано завищеною.

Все це свідчить, що очні відділення ЦРЛ в більшій мірі $є$ відділеннями офтальмотерапевтичного профілю, ніж - офтальмохірургічного, хоча мають рівень ресурсного забезпечення та кваліфікацію лікарського персоналу відповідну для відділень хірургічного профілю.

Висновок. Проведеним дослідженням встановлено, що використання мережі та ліжкового фонду стаціонарних очних відділень ЦРЛ є малоефективним, що не забезпечує високої доступності сільського дорослого населення до якісної офтальмохірургучної допомоги, а також не сприяє зниженню собівартості цієї допомоги на рівні держави. 
Динаміка забезпечення офтальмохірургічними втручаннями в умовах очного стаціонару (на 10 тис. сільського дорослого населення)

\begin{tabular}{|c|c|c|c|c|c|c|c|c|}
\hline \multirow[t]{2}{*}{ Області } & \multicolumn{7}{|c|}{$\begin{array}{c}\text { Показник кількості операцій на очах у стаціонарі } \\
\text { (на } 10 \text { тис. дорослого сільського населення) }\end{array}$} & \multirow{2}{*}{$\begin{array}{c}\text { Середнє } \\
\text { значення }\end{array}$} \\
\hline & 2002 & 2003 & 2004 & 2005 & 2006 & 2007 & 2008 & \\
\hline Вінницька & 30,5 & 37,0 & 37,2 & 40,6 & 41,2 & 43,3 & 44,4 & 39,2 \\
\hline Сумська & 37,2 & 37,8 & 39,4 & 39,5 & 39,1 & 40,2 & 39,4 & 38,9 \\
\hline АР Крим & 37,5 & 38,6 & 36,9 & 38,0 & 35,5 & 36,6 & 37,1 & 37,2 \\
\hline Донецька & 33,8 & 35,1 & 36,0 & 38,3 & 37,4 & 38,7 & 39,4 & 37,0 \\
\hline Дніпропетровська & 28,1 & 30,2 & 33,5 & 38,1 & 40,7 & 37,0 & 33,8 & 34,5 \\
\hline Луганська & 31,9 & 33,8 & 34,0 & 34,2 & 32,9 & 33,9 & 34,7 & 33,6 \\
\hline Харківська & 32,2 & 33,3 & 31,0 & 32,8 & 32,1 & 34,4 & 39,1 & 33,6 \\
\hline Запорізька & 27,7 & 31,9 & 34,8 & 34,5 & 33,1 & 33,6 & 35,2 & 33,0 \\
\hline Чернігівська & 26,4 & 28,9 & 28,7 & 35,4 & 36,0 & 34,1 & 37,6 & 32,4 \\
\hline Миколаївська & 31,0 & 33,3 & 32,0 & 31,2 & 30,4 & 27,7 & 27,2 & 30,4 \\
\hline Житомирська & 25,5 & 27,4 & 28,1 & 30,2 & 30,5 & 32,2 & 33,9 & 29,7 \\
\hline Середнє значення & 24,7 & 26,4 & 27,3 & 29,0 & 28,7 & 29,7 & 29,7 & 27,9 \\
\hline Волинська & 20,5 & 22,0 & 23,3 & 25,9 & 30,7 & 31,2 & 32,7 & 26,6 \\
\hline Рівненська & 24,0 & 24,1 & 27,2 & 26,4 & 26,3 & 28,3 & 29,1 & 26,5 \\
\hline Херсонська & 23,4 & 22,4 & 22,7 & 26,1 & 28,0 & 30,2 & 31,4 & 26,3 \\
\hline Львівська & 20,2 & 20,6 & 23,3 & 24,8 & 24,9 & 28,6 & 29,2 & 24,5 \\
\hline Кіровоградська & 17,2 & 19,6 & 22,6 & 25,9 & 24,5 & 28,0 & 31,3 & 24,2 \\
\hline Закарпатська & 21,6 & 22,7 & 26,8 & 27,6 & 24,9 & 27,2 & 18,2 & 24,1 \\
\hline Полтавська & 22,7 & 23,7 & 22,6 & 24,1 & 24,1 & 25,8 & 25,8 & 24,1 \\
\hline Черкаська & 22,8 & 23,7 & 23,8 & 25,1 & 23,3 & 23,9 & 24,2 & 23,8 \\
\hline Чернівецька & 22,2 & 22,6 & 24,1 & 25,3 & 22,9 & 22,1 & 21,0 & 22,9 \\
\hline Хмельницька & 15,6 & 20,7 & 23,7 & 24,6 & 23,5 & 21,6 & 24,0 & 22,0 \\
\hline Київська & 17,4 & 19,2 & 19,0 & 20,9 & 19,0 & 20,6 & 20,2 & 19,5 \\
\hline Тернопільська & 15,1 & 16,7 & 17,2 & 18,8 & 19,0 & 29,0 & 20,0 & 19,4 \\
\hline Одеська & 19,1 & 18,1 & 18,4 & 19,8 & 19,9 & 18,3 & 18,1 & 18,8 \\
\hline Івано-Франківська & 14,6 & 16,4 & 16,4 & 17,6 & 16,9 & 16,5 & 16,7 & 16,4 \\
\hline
\end{tabular}

Вищезазначене спонукає до проведення організаційного реформування мережі та ліжкового фонду очних відділень ЦРЛ шляхом:

- створення в області (на базі окремих очних відділень ЦРЛ) міжрайонних спеціалізованих стаціонарних відділень офтальмохірургії для мікрохірургічного лікування катаракти, глаукоми, травм ока, відшарувань сітківки тощо;

- перепрофілювання очних стаціонарних відділень ЦРЛ у відділення реабілітаціі;

- розширення на базі ЦРЛ мережі відділень амбулаторної офтальмохірургії та лазерної офтальмохірургії.

Також доцільним є створення на базі амбулаторно-поліклінічних закладів ЦРЛ міжрайонних відділень мобільної офтальмологічної допомоги, яки б дозволили забезпечити доступність населення сільської місцевості до допомоги за організаційною формою - «стаціонар на дому».

Отримані у дослідженні дані є науковим підгрунтям для реформування організаційної систем офтальмологічної допомоги на селі.

\section{ЛІТЕРАТУРА}

1. Заможне суспільство, конкурентоспроможна економіка, ефективна держава : Програма економічних реформ України на 2010-2014 рр. // Комітет з економічних реформ при Президентові України. - К., 2010. $-87 \mathrm{c}$.

2. Лехан В. М. Аналіз доступності медичної допомоги для населення України / В. М. Лехан, Л. В. Крячкова, Є. К. Духовенко // Головна медична сестра. - 2009. № 1. - С.19-20.

3. Лехан В. М. Нерівність у доступності медичної допомоги для населення України / В. М. Лехан, Л. В. Крячкова // Україна. Здоров'я нації. - 2009. - № 1/2. C.148-152.

4. Риков С. О. Наукове обгрунтування системи надання офтальмологічної допомоги населенню України: дисертація на здобуття наукового ступеня доктора медичних наук. 14.02.03; 14.01.18 // Нац. мед. ун-т ім. О. О. Богомольця. - К., 2004. - 462 с.

5. Ферфильфайн И. Л. Инвалидизирующие ограничения жизнедеятельности детей и взрослых вследствие патологии глаз. Медико-социальная экспертиза: Моногр. // И. Л. Ферфильфайн, Т. А. Алифанова. - Д.: Пороги, 2006. -274 с. 
Динаміка забезпечення офтальмохірургічними втручаннями в амбулаторних умовах

(на 10 тис. сільського дорослого населення)

\begin{tabular}{|c|c|c|c|c|c|c|c|c|c|}
\hline \multirow{2}{*}{ Області } & \multicolumn{8}{|c|}{$\begin{array}{l}\text { Показник кількості амбулаторних операцій на оці } \\
\text { (на } 10 \text { тис. сільського населення) }\end{array}$} & \multirow{2}{*}{$\begin{array}{l}\text { \% до всіх } \\
\text { втручань }\end{array}$} \\
\hline & 2002 & 2003 & 2004 & 2005 & 2006 & 2007 & 2008 & $\begin{array}{c}\text { Середнє } \\
\text { значення }\end{array}$ & \\
\hline Вінницька & 47,1 & 62,7 & 67,4 & 67,5 & 74,1 & 72,5 & 78,1 & 67,1 & 63,1 \\
\hline Волинська & 59,6 & 66,7 & 72,1 & 63,0 & 66,4 & 64,8 & 64,5 & 65,3 & 71,1 \\
\hline Рівненська & 34,6 & 40,1 & 40,9 & 43,6 & 52,4 & 57,6 & 65,3 & 47,8 & 64,3 \\
\hline Сумська & 27,2 & 31,5 & 37,2 & 44,3 & 46,5 & 50,6 & 50,6 & 41,1 & 51,4 \\
\hline Житомирська & 29,3 & 30,7 & 34,8 & 36,3 & 39,0 & 43,6 & 45,5 & 37,0 & 55,5 \\
\hline Полтавська & 28,7 & 27,0 & 22,4 & 29,0 & 31,0 & 30,7 & 28,8 & 28,2 & 53,9 \\
\hline Дніпропетровська & 17,0 & 18,4 & 20,8 & 26,4 & 29,4 & 36,6 & 44,5 & 27,6 & 44,4 \\
\hline Чернівецька & 11,8 & 10,9 & 12,0 & 15,9 & 21,7 & 23,1 & 94,6 & 27,1 & 54,2 \\
\hline Середнє значення & 20,8 & 21,9 & 23,4 & 25,5 & 27,9 & 28,9 & 34,9 & 26,2 & 48,4 \\
\hline Хмельницька & 19,6 & 19,7 & 19,8 & 23,2 & 30,9 & 28,7 & 39,8 & 26,0 & 54,2 \\
\hline Івано-Франківська & 17,7 & 19,1 & 24,0 & 24,5 & 26,9 & 25,0 & 39,9 & 25,3 & 60,7 \\
\hline Чернігівська & 14,9 & 18,1 & 19,0 & 24,1 & 29,9 & 31,8 & 30,9 & 24,1 & 42,7 \\
\hline Тернопільська & 25,9 & 21,4 & 21,4 & 23,1 & 23,9 & 26,8 & 26,3 & 24,1 & 55,4 \\
\hline Черкаська & 17,9 & 16,8 & 17,3 & 19,0 & 21,2 & 20,0 & 35,5 & 21,1 & 47,0 \\
\hline Харківська & 11,9 & 13,7 & 20,3 & 22,5 & 25,9 & 26,7 & 25,7 & 21,0 & 38,5 \\
\hline Кіровоградська & 15,0 & 13,7 & 17,7 & 21,6 & 20,6 & 22,8 & 22,2 & 19,1 & 44,1 \\
\hline Луганська & 18,4 & 18,1 & 18,0 & 19,3 & 18,3 & 19,0 & 18,9 & 18,6 & 35,6 \\
\hline Закарпатська & 17,3 & 14,3 & 15,8 & 17,1 & 21,2 & 20,2 & 22,4 & 18,3 & 43,2 \\
\hline Донецька & 15,7 & 14,9 & 17,0 & 17,5 & 18,1 & 18,8 & 18,7 & 17,2 & 31,7 \\
\hline АР Крим & 17,9 & 16,5 & 19,6 & 16,5 & 13,8 & 16,6 & 18,0 & 17,0 & 31,4 \\
\hline Херсонська & 12,3 & 13,7 & 15,9 & 17,3 & 16,0 & 16,4 & 17,6 & 15,6 & 37,2 \\
\hline Запорізька & 15,1 & 13,8 & 14,3 & 16,1 & 16,4 & 15,3 & 16,4 & 15,3 & 31,7 \\
\hline Одеська & 10,3 & 12,0 & 11,3 & 15,4 & 15,7 & 17,7 & 20,1 & 14,6 & 43,7 \\
\hline Миколаївська & 18,0 & 16,1 & 8,8 & 13,1 & 13,0 & 12,1 & 14,2 & 13,6 & 30,9 \\
\hline Львівська & 7,5 & 8,4 & 8,6 & 10,1 & 14,4 & 15,8 & 22,5 & 12,5 & 33,8 \\
\hline Київська & 8,9 & 8,5 & 9,7 & 10,2 & 11,6 & 10,4 & 11,6 & 10,1 & 34,1 \\
\hline
\end{tabular}

\section{ASSESSMENT OF AVAILABILITY OF QUALIFIED IN-PATIENT OPHTHALMOLOGIC AID TO RURAL POPULATION \\ O. Cheremukhina}

It is established that the use of the network and number of beds in the eye departments in central district hospitals is inefficient and does not provide high availability of rural adult population to qualified ophthalmologic aid as well as does not help reduce its costs at the state level. The ways of solving the existing problems are proposed. 